\title{
Tolllike receptor 4 (TLR4) polymorphisms in Tunisian patients with Crohn's disease: genotype-phenotype correlation
} Lilia Zouiten-Mekki ${ }^{* 1,2}$, Maher Kharrat ${ }^{2}$, Sami Karoui ${ }^{1}$, Mariem Serghimi ${ }^{1}$, Monia Fekih ${ }^{1}$, Samira Matri ${ }^{1}$, Lamia Kallel ${ }^{1}$, Jalel Boubaker ${ }^{1}$, Azza Filali ${ }^{1}$ and Habiba Chaabouni ${ }^{2}$

Address: ${ }^{1}$ Department of Gastroenterology A, La Rabta Hospital - 1007, Tunisia and ${ }^{2}$ Laboratory of Human Genetics, Medical school of Tunis, Tunisia

Email: Lilia Zouiten-Mekki* -w.mekki@laposte.net; Maher Kharrat - m.kharrat@rns.tn; Sami Karoui - s.karoui@rns.tn; Mariem Serghimi - m.serghini@rns.tn; Monia Fekih - m.fekih@rns.tn; Samira Matri - s.matri@rns.tn; Lamia Kallel - l.kallel@rns.tn; Jalel Boubaker - j.boubaker@rns.tn; Azza Filali - a.filali@rns.tn; Habiba Chaabouni - H.chaabouni@rns.tn

* Corresponding author

BMC Gastroenterology 2009, 9:62 doi:10.1186/1471-230X-9-62

This article is available from: http://www.biomedcentral.com/I47I-230X/9/62

(c) 2009 Zouiten-Mekki et al; licensee BioMed Central Ltd.

This is an Open Access article distributed under the terms of the Creative Commons Attribution License (http://creativecommons.org/licenses/by/2.0), which permits unrestricted use, distribution, and reproduction in any medium, provided the original work is properly cited.

\begin{abstract}
Background: The immune responses to bacterial products through the pattern recognition receptor (PRR) play a pivotal role in pathogenesis of Crohn's disease. A recent study described an association between CD and some gene coding for bacterial receptor like NOD2/CARDI 5 gene and TLR4. In this study, we sought to determine whether TLR4 gene was associated with Crohn's disease (CD) among the Tunisian population and its correlation with clinical manifestation of the disease.

Methods: 90 patients with CD and 80 healthy individuals are genotyped for the Asp299Gly and Thr399/le polymorphisms by restriction fragment length polymorphism analysis.

Results: The allele and genotype frequency of the TLR4 polymorphisms did not differ between patients and controls. The genotype-phenotype correlation permitted to show that the Thr399lle polymorphism was associated with early onset disease.

Conclusion: this study reported the absence of association between CD and TLR4 gene in the Tunisian population, but this gene could play a role in clinical expression of the disease.
\end{abstract}

\section{Background}

Inflammatory bowel disease (IBD) is a multifactorial polygenic disease. Some genetic markers increase the risk of ulcerative colitis (UC) or Crohn's disease (CD) while others are associated with a particular phenotypic expression like disease location and/or behaviour $[1,2]$.

In addition to genetic predisposition, various environmental factors play a key role in the pathogenesis of IBD such as enteric bacterial flora. In IBD, a disturbed hostbacteria interaction with an aberrant mucosal immune response has been observed $[3,4]$. This basic immunological mechanism in IBD is demonstrated by the recently described association within IBD and gene coding for receptor of bacterial products. In 2001, several studies associated CD with NOD2/CARD15 gene which coding for cytosolic receptor of bacterial muramyl dipeptides [57]. The three common variants of NOD2 gene (SNP8: 
Arg702Trp; SNP12: Gly908Arg; SNP13: Leu1007insC) induce an impairment of bacterial recognition. They are associated with dysregulation of NFKB pathway and reduced $\alpha$ defensin release from paneth cells [8-10]. However, there are significant geographical differences in the frequency of these alleles [11]. These are not found among Japanese, Chinese, Australian and Tunisian population [12-15]; they are also less frequent in North European countries $[16,17]$.

Toll-like receptors 4 (TLR4) is a transmembrane protein which plays a key role in bacterial lipopolysaccharides (LPS) recognition and in initiating innate immune responses [18]. It is a receptor of bacterial LPS [19]. TLR4 deficient mice are defective in their response to LPS. TLR4 is up regulated in the intestinal epithelial cells in patients with ulcerative colitis and Crohn's disease (CD) [20]. Recently, two missense polymorphisms Asp299Gly and Thr399Ile affecting the extracellular domains of TLR4 were associated with LPS hyporesponsiveness [21-23] and an association was reported between these polymorphisms and IBD [24-26].

The aim of this study was to investigate about the presence of Asp299Gly and Thr399Ile polymorphisms of the TLR4 gene among a Tunisian population with $\mathrm{CD}$. We also aimed to investigate about any correlation between these polymorphisms and clinical phenotypes of CD.

\section{Methods}

\section{- Subjects}

The study included 90 patients with Crohn's disease, 30 patients with ulcerative colitis and 80 healthy control groups. All of them were Caucasian and the control group was matched with the patient group for sex and age.

The diagnosis of CD or UC was determined by standard clinical, radiological, endoscopic and histological criteria [27].

CD was classified according to the Vienna Classification [28]. CD patients were composed of 47 males and 43 females. Mean age was 35 years. CD was ileocolitis in 40 patients, ileitis in 22 patients and colitis in 28 patients. Mean of follow up is 90 month (24-117 month). We analysed disease behaviour at latest follow-up.

Informed consent was obtained verbally from each participant and an ethical approval was obtained by ethical committee of La Rabta Hospital.

\section{- Classification of the CD clinical phenotypes}

We also applied an arbitrary classification based on the disease severity, need for surgery and need for immunosuppressive therapy.
The severity of $\mathrm{CD}$ is evaluated by the behaviour of the disease (penetrating, stricturing or inflammatory) and the installation of an acute severe colitis requiring intensive medical therapy. Within the category of severe $\mathrm{CD}$, patients requiring immunosuppressive therapy or surgery were categorized under the phenotype "need for surgery" or "need for immunosuppressive".

Other phenotypic details such as disease location, age at diagnosis and presence of extra intestinal manifestations, were also recorded.

\section{- PCR analysis of TLR4 alleles}

Genomic DNA was extracted from peripheral blood leukocytes. The two mutations of the TLR4 gene (Asp299Gly and Thr399Ile) were performed using polymerase chain reaction (PCR) and restriction fragment length polymorphism analysis (RFLP). To amplify the coding regions, we used the following primers:

for TLR4 Asp299Gly F: (5'AGCATACTTAGACTACTACCT CCATG3'), R: (5'GAGAGATTTGAGTTTCAATGTGGG3')

and for TLR4 Thr399Ile F: (5'GGTTGCTGTTCTCAAAGTG ATTTTGGGAGAA3'), R: (5'GGAAATCCAGATGTTCTAGT TGTTCTAAGCC3').

The PCR was carried out by 30 cycles of denaturing at $94^{\circ} \mathrm{C}$ for $1 \mathrm{~min}$, annealing at $55^{\circ} \mathrm{C}$ (Asp299Gly) and at $53^{\circ} \mathrm{C}$ (Thr399Ile) for $1 \mathrm{~min}$, and extension at $72^{\circ} \mathrm{C}$ for 1 min. PCR products were cleaved overnight with Nco I for Asp299Gly polymorphism and HinfI for Thr399Ile polymorphism (Biolabs) at $37^{\circ} \mathrm{C}$ and electrophored on a $2,5 \%$ agarose gel. The fragment sizes for carriers of the polymorphic allele decreased from 188 bp (wild type: alleleA) to $168 \mathrm{bp}$ (allele G) for the Asp299Gly polymorphism and from $124 \mathrm{bp}$ (wild type: allele C) to $98 \mathrm{bp}$ (allele T) for the Thr399Ile polymorphism.

\section{- Statistical analysis}

Chi square test was used to compare the allele and genotype frequencies among disease and control groups. To correlate phenotype genotype state, the T-student test was used for quantitative parameters and Fischer test for qualitative parameters. The Kaplan-Meir with Log-Rank test was used to compare the delay of surgery within the different groups. P values less than 0.05 were considered significant.

\section{Results}

Genotype frequency and allele distribution of TLR4 Asp299Gly polymorphism are summarized in table 1 . The genotype GG was not found in both patients and control groups. The frequencies of the 299Gly allele were respectively, $7,5 \%$ and $6 \%$ in CD and healthy controls. No sig- 
Table I: TLR4 Asp299Gly polymorphism: Genotype and allele frequencies (\%) of in Crohn's disease (CD) patients and controls.

\begin{tabular}{cccc}
\hline & CD $(n=90)$ & Controls $(n=80)$ & $P$ \\
\hline $\begin{array}{c}\text { Genotype } \\
\text { AA }\end{array}$ & $86 \%(78)$ & $89 \%(7 I)$ & 0.6 \\
AG & $14 \%(12)$ & $11 \%(9)$ & \\
GG & 0 & 0 & \\
\hline Alleles & & & 0.6 \\
A & $93 \%(168)$ & $94 \%(15 I)$ & \\
G & $7 \%(12)$ & $6 \%(9)$ & \\
\hline
\end{tabular}

nificant difference was noticed in the Asp299Gly polymorphism frequencies among CD patients and controls.

TLR4 Thr399Ile genotype carrier frequencies are summarized in table 2. None patients and control, were homozygote for allele $\mathrm{T}$. The allele $\mathrm{T}$ was more frequent in $\mathrm{CD}$ patient than controls ( $7 \%$ and $4,5 \%$ respectively) but the difference was not significant. The distribution of Thr399Ile polymorphism was similar in UC group, CD and controls.

The correlation study between Asp299Gly polymorphism and phenotype of CD didn't either allow to associate TLR4 genotype with specific disease behaviour, or with the severity of $\mathrm{CD}$. Whereas, for Thr399Ile polymorphism, we noted an earlier onset of disease in CD patients carrying allele $\mathrm{T}$ ( 27 years \pm 9 vs 36 years \pm 10 ). This difference is statistically significant $(\mathrm{p}=0.01)$ (table 3$)$.

Different analyses, based on the time between the diagnosis of the complication and the onset of the disease: stricturing or penetrating form, acute severe colitis, need for surgery or immunosuppressive therapy, have been studied. No significant differences were noticed between these parameters and genotype (Figure 1 and Figure 2).

The extraintestinal manifestations are observed in $20 \%$ of patients but only three of them have TLR4 mutations.

Table 2: TLR4 Thr399lle polymorphism: Genotype and allele frequencies (\%)in Crohn's disease (CD) patients and controls.

\begin{tabular}{|c|c|c|c|c|}
\hline & $C D(n=90)$ & $U C(n=30)$ & Controls $(n=80)$ & $P$ \\
\hline Genotype & & & & 0.38 \\
\hline $\mathrm{CC}$ & $86 \%(77)$ & $93 \%(28)$ & $90 \%(72)$ & \\
\hline CT & $14 \%(13)$ & $7 \%(2)$ & $10 \%(8)$ & \\
\hline TT & 0 & 0 & 0 & \\
\hline \multicolumn{5}{|l|}{ Alleles } \\
\hline C & $93 \%(167)$ & $97 \%(58)$ & $95 \%(152)$ & 0.5 \\
\hline $\mathrm{T}$ & $7 \%(13)$ & $3 \%(2)$ & $5 \%(8)$ & \\
\hline
\end{tabular}

We also evaluated the co-existence of TLR4 mutations and those of NOD2 and HSP70-2 genes in CD patients (previous studies for the same patients) [12-29]. The number of patients carrying a TLR4 mutations and one of NOD2 and/or HSP70-2 mutations, was 20 (19\%) vs $17 \%$ in controls subjects. Statistically, no difference was noticed between patients and controls.

The co-existence of TLR4 mutations was associated with prevalent complications of CD $(73 \%$ vs $27 \% \mathrm{p}=0.06)$. Three of CD patients were carrying simultaneously a polymorphic allele of the three tested genes. These patients have a severe form of the disease.

Additionally, $76 \%$ of the CD patients were carrying one mutation of TLR4 gene, in minimum, compared to $65 \%$ in controls group $(\mathrm{p}=0.09)$.

\section{Discussion}

Following the identification of the NOD2/CARD15 gene in $\mathrm{CD}$, the role of innate immune system in the pathogenesis of IBD has gained an increasing attention. Compared to mutations in the cytosolic receptor NOD2/CARD15, the TLR4 polymorphisms caused an impaired response to LPS [30]. Cario and Podolsky showed that TLR4 was strongly up-regulated in CD and UC [20], this may be caused by an exaggerated host defence reaction of the intestinal epithelium to endogenous luminal bacterial flora [31].

The importance of TLR4 polymorphisms in CD is less clear than NOD2/CARD15. In healthy Caucasians, the reported frequencies of these polymorphisms ranges are between $7 \%$ and $12 \%$ [32].

Franchimont et al. have reported a two-fold elevation in allele frequency of TLR4 Asp299Gly in CD Belgium patients [26]. The Thr399lle variant was associated with UC in German study [24]. Japanese [30] and Hungarian studies [33] failed to detect any individuals displaying the mutant alleles in TLR4. There is also no difference in TLR4 allele frequency between IBD patients and controls in preliminary results of the EC-IBD study group [17].

These finding comfort our results, since in our study, about TLR4 polymorphisms, no significant differences in the allele or genotype frequencies between the study groups were noticed. The small size of our cohort may contribute to these negative results.

The correlative study between TLR4 mutations and CD, allowed us to show an early disease onset in the subgroup of patients, carrying a Thr399Ile variant in our study (27 years \pm 9 vs 36 years $\pm 10 ; \mathrm{p}=0.01$ ). 
Table 3: TLR4 alleles and clinical characteristics of CD patients.

\begin{tabular}{|c|c|c|c|c|}
\hline & \multicolumn{2}{|c|}{ Asp299Gly } & \multicolumn{2}{|c|}{ Thr399lle } \\
\hline & $\mathrm{G}(\%)$ & $A(\%)$ & $\mathrm{T}(\%)$ & $\mathrm{C}(\%)$ \\
\hline \multicolumn{5}{|l|}{ Sex } \\
\hline$M$ & 9 & 43 & 9,5 & 41,5 \\
\hline $\mathrm{F}$ & 7 & $4 I, 5$ & 5 & 44 \\
\hline Age (years) & $30 \pm 12$ & $36 \pm 12$ & $27 \pm 9$ & $36 \pm 10^{*}$ \\
\hline \multicolumn{5}{|l|}{ Location } \\
\hline Ileum & 5 & 19 & 1 & 21 \\
\hline Ileocolic & 6 & 37 & 6 & 37 \\
\hline Colon & 3 & 28 & 7 & 27 \\
\hline Anoperineal manifestations & 2 & 28 & 2 & 28 \\
\hline Penetrating and/or Stricturing form & 11 & 47 & 9,5 & 50 \\
\hline Acute severe colitis & 3 & 12 & 3,5 & 15 \\
\hline Need for immunosuppressive & 8 & 31,4 & 7 & 36 \\
\hline
\end{tabular}

$*: p=0.01$

In literature, the presence of variant TLR4 allele was tendency to be associated with an early disease onset in Hungarian study $(\mathrm{p}=0.06)$; the earliest onset was observed in carriers of both variant NOD2/CARD15 and TLR4 alleles (23 years vs 30.2 years; $\mathrm{p}=0.01$ )[33]. These results differ from those of another study that doesn't establish any association between TLR4 polymorphisms and the age of the disease onset [34]. This discrepancy of results necessities more study with a large cohort.

Ouburg et al. [35] described an association between the TLR4 polymorphisms and colonic localisation (43\% vs
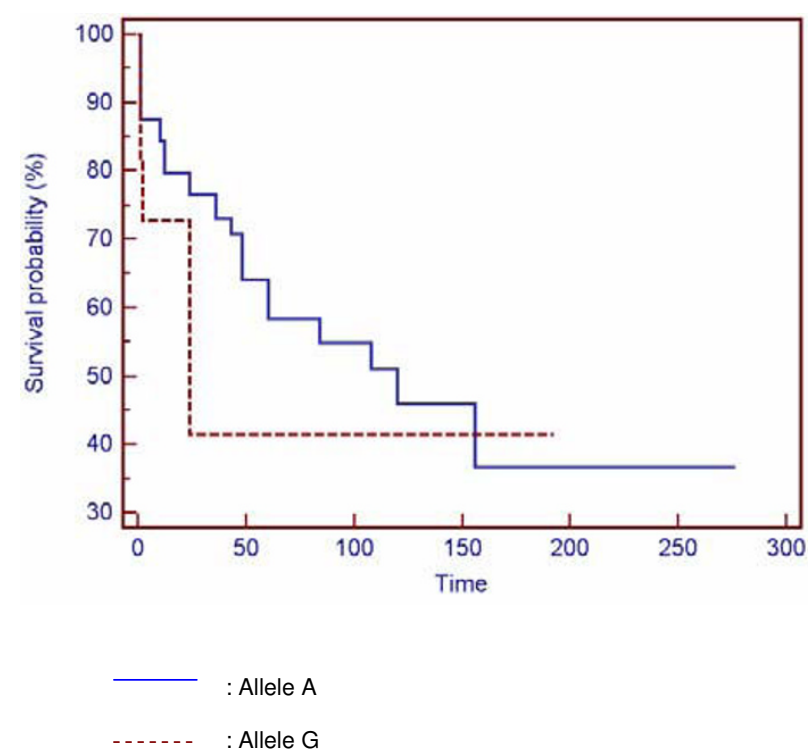

\section{Figure I}

Comparison of the delay of surgery between allelic variants of Asp299Gly polymorphism.
$12 \% ; p=0.0017)$. This association could not be confirmed in our study.

The three candidate genes of CD: NOD2, HSP70-2 and TLR4, studied in the Tunisian population, were not associated with the disease among our population, contrarily to European and American results [29,36-38].

The co-existence of TLR4, NOD2/CARD15, HSP70-2 mutated alleles is distributed similarly in CD and control group. It seems that these genes don't increase the risk of

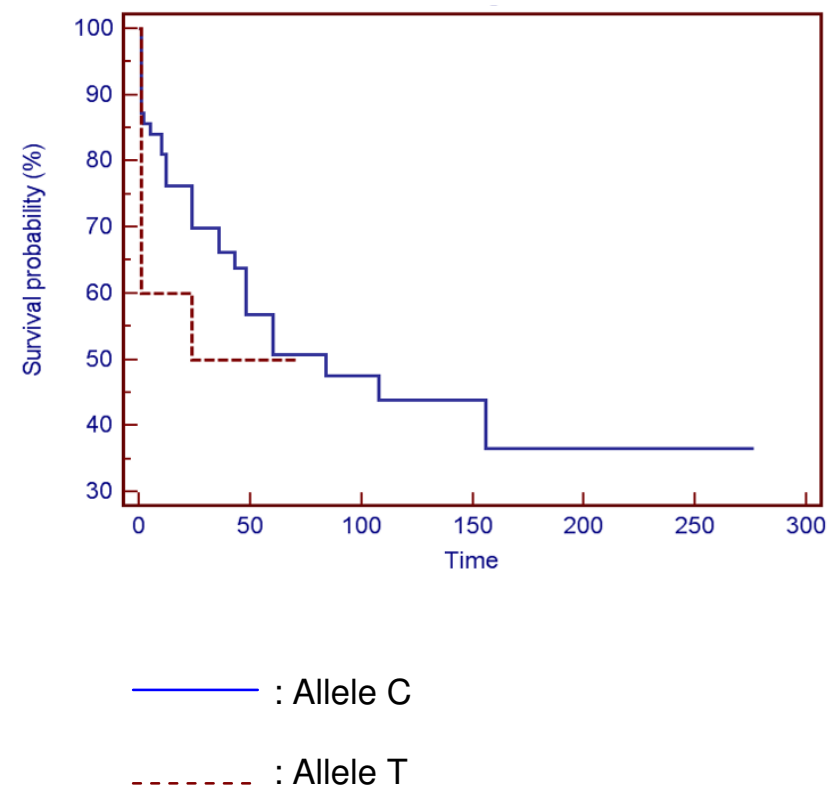

Figure 2

Comparison of the delay of surgery between allelic variants of Thr399/le polymorphism. 
developing the disease, but they play probably a role in phenotype determines, since more complications were noticed within patients carrying two or more mutations $(\mathrm{p}=0.06)$.

Three patients were found to carry mutations in all three genes. These patients had an earlier disease onset $(19,23$ et 30 years), an ileocolitis location, a stricturing perforating form and anoperinal manifestations and then, a severe form of the disease.

Analysing the SNP interaction will allow an understanding of the phenotypic variation of the disease, but until now the results in $\mathrm{CD}$ are controversial. In fact, some studies show that the coexistence of mutations of NOD2/ CARD15 and TLR4 genes, increase the risk of developing $\mathrm{CD}$ [39-43] or, is associated with the phenotype of the disease, but these results were not confirmed.

\section{Conclusion}

In conclusion, our study is unable to detect an association within the TLR4 gene and CD, but this gene could be implicated in the phenotype of the disease, mainly with early onset of disease. The co-existence of several allelic variant of TLR4, NOD2/CARD15 and HSP70-2 genes may be associated with severe form of the Crohn's disease among the Tunisian population.

The association between NOD2/CARD15, HSP70-2 and TLR4 mutations with $C D$ varies from a population to another; within the USA, European, Asiatic or the Tunisian population. Further genetic studies should definitely resolve the impact of these genes in susceptibility to $\mathrm{CD}$, depending on the ethnic background.

\section{Abbreviations}

CD: Crohn's disease; PCR: polymerase chain reaction.

\section{Competing interests}

The authors declare that they have no competing interests.

\section{Authors' contributions}

LMZ carried out the molecular genetic studies, participated in the recruitment of the patients and drafted the manuscript. M K participated in the molecular genetic studies. SK performed the statistical analysis and participated to the recruitment of patients. MS, MF, LK, SM and JB participated in the recruitment of patients. AF and HC conceived of the study, participated in its design and coordination and helped to draft the manuscript. All authors read and approved the final manuscript.

\section{References}

I. Cantor MJ, Nickerson P, Bernstein CN: The role of cytokine gene polymorphisms in determining disease susceptibility and phenotype in inflammatory bowel disease. Am J Gastroenterol 2005, I00(5): I I34-42.

2. Ahmad T, Tamboli PC, Jewell D: Clinical relevance of advances in Genetics and pharmacogenetics of IBD. Gastroenterology 2004, I 26: I533-1549.

3. Mathew CG, Lewis CM: Genetics of inflammatory bowel disease: progress and prospects. Hum Mol Genet 2004, I3:RI6I-RI68.

4. Newmann B, Siminovitch KA: Recent advances in the genetics of inflammatory bowel disease. Curr Opin Gastroenterol 2005, 2I(4):40I-7.

5. Ogura Y, Bonen DK, Inohra N, Nicolae DL, Chen FF, Ramos R, Britton H, Moran T, Karaliuskas R, Duerr RH, Achkar JP, Brant SR, Bayless TM, Kirshner BS, Hanauer SB, Nunez G, Cho JH: A frameshift mutation in NOD2 associated with susceptibility to Crohn's disease. Nature 200 I, 4I I:603-606.

6. Hugot JP, Chamaillard M, Wouali H, Lesage S, Cezard JP, Belaiche J, Almer S, Tysk C, O'Morain CA, Gassul M, Binder V, Finkel Y, Cortot A, Modigliani R, Laurent Puig P, Gower Rousseau C, Macry J, Colombel JF, Sahbatou M, Thomas G: Association of NOD 2 leucine repeat variants with susceptibility to Crohn's disease. Nature 200 I, 4I I:599-603.

7. Hampe J, Cuthbert A, Croucher PJ, Mirza MM, Mascheretti S, Fisher S, Frenzel H, King K, Hasselmeyer A, MacPherson AJ, Bridger S, Van Deventer S, Forbes A, Nikolaus S, Lennard Jones JE, Foelsch UR, Krawczak M, Lewis C, Schreiber S, Mathew CG: Association between insertion mutation in NOD2 gene and Crohn's disease in German and British populations. Lancet 200I, 357:1925-1928.

8. Bonen DK, Ogura Y, Nicolae DL: Crohn's disease-associated NOD2 variants share a signaling defect in response to lipopolysaccharide and peptidoglycan. Gastroenterology 2003, 124:140-146.

9. Inohara N, Ogura $Y$, Fontalba A: Host recognition of bacterial muramyl dipeptide mediated through NOD2. Implications for Crohn's disease 2003, 278:5509-55। 2.

10. Girardin SE, Boneca IG, Viala J: Nod2 is a general sensor of peptidoglycan through muramyl dipeptide (MDP) detection. J Biol Chem 2003, 278:8869-8872.

II. Fort MM, Mozaffarian A, Stover AG, Correia Jda S, Johnson Marsh S, McLeod HL: Crohn's disease: ethnic variation in CARDI 5 genotypes. Gut 2003, 52:770.

12. Zouiten-Mekki L, Zouali H, Boubaker J: CARDI5/NOD2 in Tunisian population with Crohn's disease. Dig Dis Sci 2005, 50(I): $130-135$

13. Inoue N, Tamura K, Kinouchi Y, Fukuda Y, Takahashi S, Ogura Y, Inohara N, Nunez G, Kishi Y, Koike Y, Shimosegawa T, Shimoyama T, Hibi T: Lack of common NOD2 variants in Japanese patients with Crohn's disease. Gastroenterology 2002, I 23:86-9I.

14. Yamazaki K, Takazoe M, Tanaka T, Kazumori T, Nakamura Y: Absence of mutation in the NOD2/CARD I 5 gene among 483 Japanese patients with Crohn's disease. J Hum Genet 2002, 47:469-472.

15. Leong RW, Armuzzi A, Ahmad T, Wong ML, Tse P, Jewell DP, Sung Jj: NOD2/CARD I 5 gene polymorphisms and Crohn's disease in the Chinese population. Aliment Pharmacol Ther 2003, 17:1465-1470.

16. Croucher PJ, Mascheretti S, Hampe J, et al.: Haplotype structure and association to Crohn's disease of CARDI 5 mutations in two ethnically divergent populations. Eur J Hum Genet 2003, II:6-16.

17. Riis LB, Wolters F, Solberg C: Regional differences in the prevalence of single nucleotide polymorphisms in CARD I 5/NOD2 but not in toll-like receptor 4 (TLR4) Asp299Gly polymorphism in patients with inflammatory bowel disease (IBD) across Europe: Results from the EC-IBD study group. Gastroenterology 2004, I 26(Suppl S):MI539.

18. Takeda K, Kaisho T, Akira S: Toll-like receptors. Annu Rev Immunol 2003, $21: 335-376$.

19. Hornef MW, Normark BH, Vandewalle A, Normark S: Intracellular recognition of lipopolysaccharide by toll-like receptor 4 in intestinal epithelial cells. J Exp Med 2003, 198: | 225- 1235.

20. Cario $E$, Podosky DK: Differential alteration in intestinal epithelial cell expression of Toll-like receptor 3 (TLR3) and TLR4 in inflammatory bowel disease. Infect Immun 2000, 68:7010-7017. 
21. Arbour NC, Lorenz E, Schutte BC: TLR4 mutations are associated with endotoxin hyporesponsiveness in humans. Nat Genet 2000, 25: 187-19|.

22. Schmitt C, Humeny A, Becker CM, Brune K, Pahl A: Polymorphisms of TLR4: rapid genotyping and reduced response to lipopolysaccharide of TLR4 mutant alleles. Clin Chem 2002, 48: $166 \mid-1667$.

23. Erridge C, Stewart J, Poxton IR: Monocytes heterozygous for the Asp299Gly and Thr399/le mutations in the Toll-like receptor 4 gene show no deficit in lipopolysaccharide signaling. J Exp Med 2003, 197:1787-1791.

24. Torok HP, Glas J, Tonenchi L, Mussack T, Folwaczny C: Polymorphisms of the lipopolysaccharide-signaling complex in inflammatory bowel disease: association of a mutation in the toll-like receptor 4 gene with ulcerative colitis. Clinical immunology 2004, I I 2:85-9|.

25. Gazouli M, Mantzaris G, Kotsinas A, Zacharatos P, Papalambros E, Archimandritis E, Ikonomopoulos J, Gorgoulis VG: Association between polymorphisms in the Toll-like receptor 4, CDI4 and CARDI5/NOD2 and inflammatory bowel disease in the Greek population. WJ Gastroenterol 2005, I I:68I-685.

26. Franchimont D, Vermeir S, El Housni H, Pierik M, Van Steen K, Gustot T, Quertinmont E, Abramowicz M, Van Gossum A, Devière J, Rutgeerts $P$ : Deficient host-bacteria interactions in inflammatory bowel disease? The toll-like receptor (TLR)-4 Asp 299Gly polymorphism is associated with Crohn's disease and ulcerative colitis. Gut 2004, 53:987-992.

27. Kornbluth A, Salomon P, Sachar DB: Crohn's disease. In Gastrointestinal disease: pathophysiologie/diagnosis/management Volume 2. 5th edition. Edited by: Sleisenger MH, Fordtran JS. Philadelphia: Sanders; 1993:1270-302.

28. Gasche C, Scholmerich J, Brynskov J: A simple classification of crohn's disease report of the working party for the world congressess of gastroenterology Vienna 1998. Inflamm Bowel Dis 1998, 6:8-15.

29. Zouiten-Mekki L, Karoui S, Kharrat M, et al.: Crohn's disease and polymorphism of heat Shock Protein gene HSP70-2 in Tunisian population. Eur J Gastroenterol Hepatol 2007, 19(3):225-228.

30. Agnese DM, Calvano JE, Hahm SJ, Coyle SM, Corbett SA, Calvano SE, Lowry SF: Human Toll-Like Receptor 4 Mutations but Not CD 4 Polymorphisms Are Associated with an Increased Risk of Gram-Negative Infections. J Inf Diseases 2002, 186: I 522-5.

31. Rakoff-Nahoum S, Paglino J, Eslami-Varzaneh F, et al.: Recognition of commensal microflora by toll-like receptors is required for intestinal homeostasis. Cell 2004, I I 8:229-4I.

32. Okayama N, Fujimura K, Suehiro Y, et al:: Simple genotype analysis of the Asp299Gly polymorphism of the toll-like receptor4 gene that is associated with lipopolysaccharide hyporesponsiveness. J Clin Lab Anal 2002, 16:56-8.

33. Lakatos PL, Lakatos L, Szalay F, Willheim-Polli C, Österreicher C, et al.: Toll-like receptor 4 and NOD2/CARDI5 mutations in Hungarian patients with Crohn's disease: Phenotype-genotype correlations. World I Gastroenterol 2005, I I: | 489- | 495.

34. Leshinsky-silver E, Karban A, Buzhakor E, Fridlander M, Yakir B, Eliaakim R, Reif S, Shaul R, Boaz M, Lev D, Levine A: Is age of onset of Crohn's disease governed by mutations in NOD2/caspase recruitment domains 15 and Toll-like receptor 4? Evaluation of a pediatric cohort. Pediatr Res 2005, 58:499-504.

35. Ouburg S, Mallant-Hent R, Crusius JBA, van Bodegraven AA, Mulder C], Linskens R, Pena AS, Morre SA: The toll-like receptor 4 (TLR4) Asp299Gly polymorphism is associated with colonic localisation of Crohn's disease without a major role for the Saccharomyces cerevisiae mannan-LBP-CDI4-TLR4 pathway. Gut 2005, 54:439-440.

36. Debler J, Schiemann U, Seybold U, et al.: Heat-shock protein HSP 70-2 genotypes in patients with Crohn's disease: a more severe clinical course with intestinal complications in presence of the Pstl-polymorphism. Eur J Med Res 2003, 27:120-4.

37. Esaki M, Furuse M, Matsumoto T, et al.: Polymorphism of heat shock protein gene HSP70-2 in Crohn disease: possible genetic marker for two forms of Crohn disease. Scand J Gastroenterol 1999, 34:703-707.

38. Brand S, Staudinger T, Schnitzler F, Pfennig S, Hofbauer K, Dambacher J, Seiderer J, Tillack C, Konrad A, Crispin A, Goke B, Lohse P, Ochsenkuhn T: The role of Toll-like receptor 4 Asp299Gly and Thr399lle polymorphisms and CARD 15/NOD2 mutations in the susceptibility and phenotype of Crohn's disease. Inflamm Bowel Dis 2005, I I:645-652.

39. Arnott IDR, Nimmo ER, Drummond HE, et al:: NOD2/CARDI5, TLR4 and CDI4 mutations in Scottish and Irish Crohn's disease patients: evidence for genetic heterogeneity within Europe? Genes Immun 2004, 5:417-25.

40. Nimmo ER, Arnott IDR, Drummond HE, et al:: Mutations of tolllike receptor 4 and CD 14 genes are not associated with susceptibility or disease behaviour in inflammatory bowel disease. Gastroenterology 2003, I24(Suppl I):A373.

4I. Oostenbrug LE, De Jong D, Drenth JPH, et al.: Lack of association between toll-like receptor 4 haplotype and Asp299Gly polymorphism and susceptibility for inflammatory bowel disease. Gastroenterology 2003, I 24(SuppI I):A372.

42. Noble C, Nimmo E, Gaya D, Russell RK, Satsangi ]: Novel susceptibility genes in inflammatory bowel disease. World J Gastroenterol 2006, I 2(13): 1991-1999.

43. Arnott ID, Nimmo ER, Drummond HE, Fennell J, Smith BR, Oostenbrug LE, Drenth JP, de Jong D, Nolte IM, Oosterom E, van Dullemen $H M$, Linde $K$ van der, te Meerman G], Steege $G$ van der, Kleibeuker $\mathrm{JH}$, Jansen PL: Association between Toll like receptor $\mathbf{4}$ and inflammatory bowel disease. Inflamm Bowel Dis 2005, I I:567-575.

\section{Pre-publication history}

The pre-publication history for this paper can be accessed here:

http://www.biomedcentral.com/1471-230X/9/62/pre $\underline{\text { pub }}$
Publish with Biomed Central and every scientist can read your work free of charge

"BioMed Central will be the most significant development for disseminating the results of biomedical research in our lifetime. "

Sir Paul Nurse, Cancer Research UK

Your research papers will be:

- available free of charge to the entire biomedical community

- peer reviewed and published immediately upon acceptance

- cited in PubMed and archived on PubMed Central

- yours - you keep the copyright
BioMedcentral 